\title{
Fusion Techniques for the Oxidation of Refractory Actinide Oxides
}

by

RECORDS ADMINISTRATION

T. S. Rudisill

Westinghouse Savannah River Company

Savannah River Site

Aiken, South Carolina 29808

D. G. Karraker

This paper was prepared in connection with work done under the above contract number with the U.S.

Department of Energy. By acceptance of this paper, the publisher and/or recipient acknowledges the U. S.

Government's right to retain a nonexclusive, royalty-free license in and to any copyright covering this paper, along with the right to reproduce and to authorize others to reproduce all or part of the copyrighted paper. 


\section{DISCLAIMER}

This report was prepared as an account of work sponsored by an agency of the United States Government. Neither the United States Government nor any agency thereof, nor any of their employees, makes any warranty, express or implied, or assumes any legal liability or responsibility for the accuracy, completeness, or usefulness of any information, apparatus, product, or process disclosed, or represents that its use would not infringe privately owned rights. Reference herein to any specific commercial product, process, or service by trade name, trademark, manufacturer, or otherwise does not necessarily constitute or imply its endorsement, recommendation, or favoring by the United States Government or any agency thereof. The views and opinions of authors expressed herein do not necessarily state or reflect those of the United States Government or any agency thereof.

This report has been reproduced directly from the best available copy.

Available to DOE and DOE contractors from the Office of Scientific and Technical Information, P. O. Box 62, Oak Ridge, TN 37831; prices available from (423) 576-8401.

Available to the public from the National Technical Information Service, U. S. Department of Commerce, 5285.Port Royal Road, Springfield, VA 22161. 
Fusion Techniques for the Oxidation of Refractory Actinide Oxides

Tracy S. Rudisill and David G. Karraker

March 1999

Westinghouse Savannah River Company

Aiken, SC 29808

Prepared for the U. S. Department of Energy under Contract DE-AC09-96SR18500 
WSRC-TR-99-00021

Revision 0

Fusion Techniques for the Oxidation of Refractory Actinide Oxides

By

Tracy S. Rudisill and David G. Karraker

Issued: March 1999

\section{Approvals}

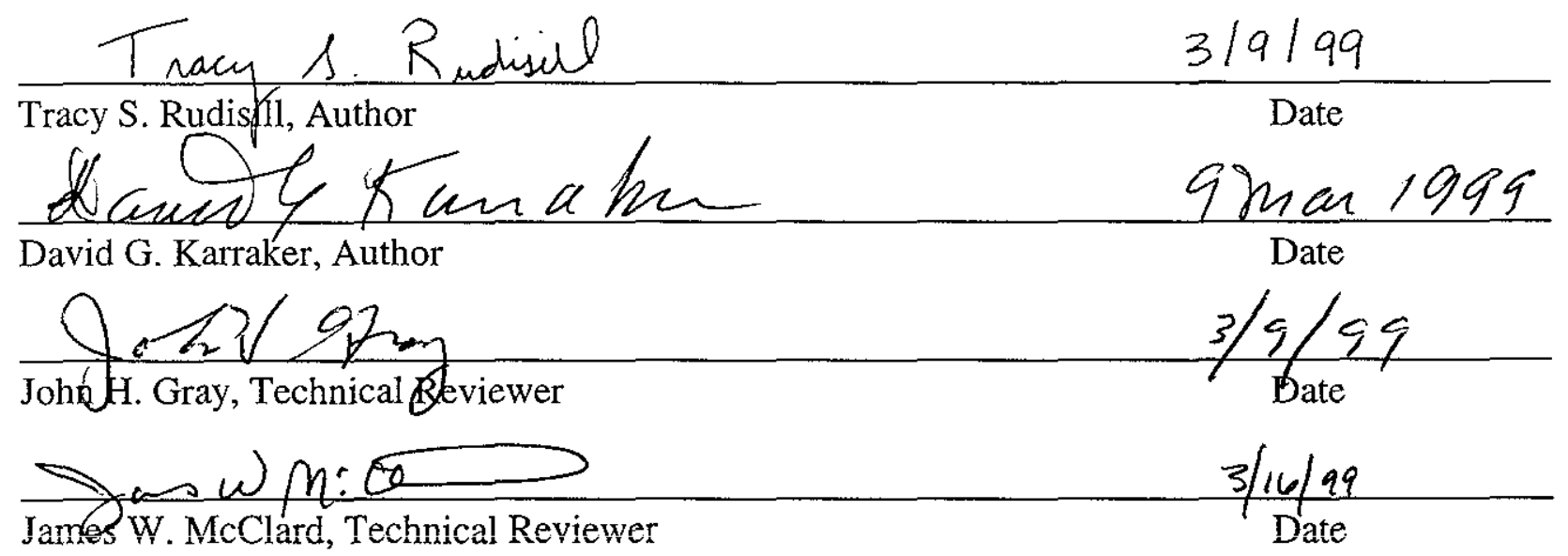




\section{Table of Contents}

Section

Page

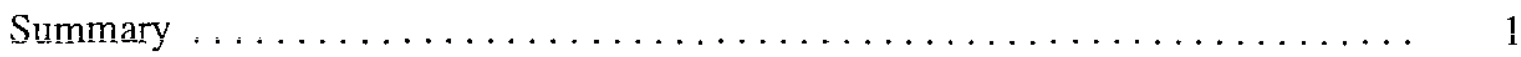

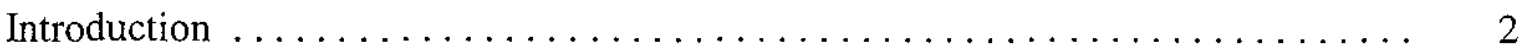

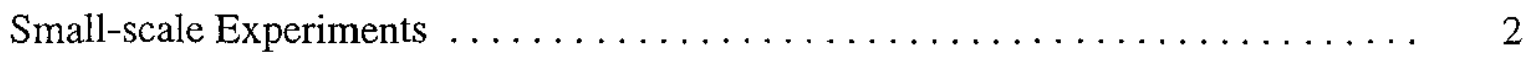

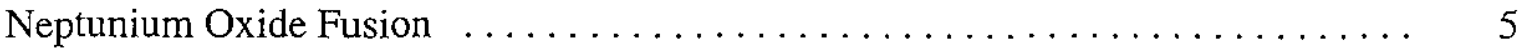

Fusion of Graphite Fines Residue $\ldots \ldots \ldots \ldots \ldots \ldots \ldots \ldots \ldots \ldots \ldots \ldots \ldots \ldots \ldots \ldots \ldots$

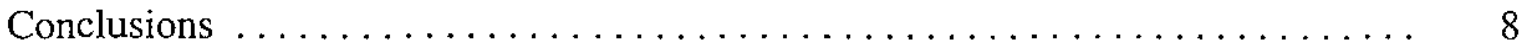

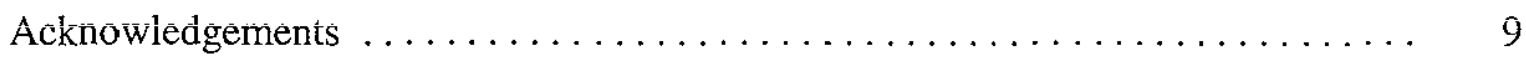

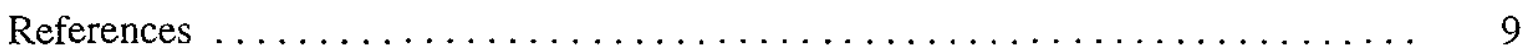

\section{List of Tables}

Table $1 \quad$ Summary of Small-Scale Fusion Experiments $\ldots \ldots \ldots \ldots$

Table 2 Plutonium Recovery Following Small-Scale Fusions $\ldots \ldots \ldots 4$

Table $3 \quad$ Fusion of $\mathrm{NpO}_{2}$ with Increasing Temperature $\ldots \ldots \ldots \ldots \ldots$

Table $4 \quad$ Composition of Graphite Fines Residue $\ldots \ldots \ldots \ldots \ldots$

Table 5 Plutonium Recovery from Graphite Fines Residue $\ldots \ldots \ldots \ldots$ 
WSRC-TR-99-00021

Revision 0

\title{
Fusion Techniques for the Oxidation of Refractory Actinide Oxides
}

\author{
Tracy S. Rudisill and David G. Karraker \\ Westinghouse Savannah River Company \\ Savannah River Site \\ Aiken, SC 29808
}

\section{Summary}

Small-scale experiments were performed to demonstrate the feasibility of fusing refractory actinide oxides with a series of materials commonly used to decompose minerals, glasses, and other refractories as a pretreatment to dissolution and subsequent recovery operations. In these experiments, $1-2 \mathrm{~g}$ of plutonium or neptunium oxide $\left(\mathrm{PuO}_{2}\right.$ or $\left.\mathrm{NpO}_{2}\right)$ were calcined at $900^{\circ} \mathrm{C}$, mixed and heated with the fusing reagent(s), and dissolved. For refractory $\mathrm{PuO}_{2}$, the most effective material tested was a lithium carbonate $\left(\mathrm{Li}_{2} \mathrm{CO}_{3}\right)$ /sodium tetraborate $\left(\mathrm{Na}_{2} \mathrm{~B}_{4} \mathrm{O}_{7}\right)$ mixture which aided in the recovery of $90 \%$ of the plutonium. The fused product was identified as a lithium plutonate $\left(\mathrm{Li}_{3} \mathrm{PuO}_{4}\right)$ by $\mathrm{x}$-ray diffraction.

The use of a $\mathrm{Li}_{2} \mathrm{CO}_{3} / \mathrm{Na}_{2} \mathrm{~B}_{4} \mathrm{O}_{7}$ mixture to solubilize high-fired $\mathrm{NpO}_{2}$ was not as effective as demonstrated for refractory $\mathrm{PuO}_{2}$. In a small-scale experiment, $25 \%$ of the $\mathrm{NpO}_{2}$ was oxidized to a neptunium (VI) species that dissolved in nitric acid. The remaining neptunium was then easily recovered from the residue by fusing with sodium peroxide $\left(\mathrm{Na}_{2} \mathrm{O}_{2}\right)$. Approximately $70 \%$ of the neptunium dissolved in water to yield a basic solution of neptunium (VII). The remainder was recovered as a neptunium (VI) solution by dissolving the residue in $8 \mathrm{M}$ nitric acid. In subsequent experiments with $\mathrm{Na}_{2} \mathrm{O}_{2}$, the ratio of neptunium (VII) to (VI) was shown to be a function of the fusion temperature, with higher temperatures (greater than approximately $400^{\circ} \mathrm{C}$ ) favoring the formation of neptunium (VII).

The fusion of an actual plutonium-containing residue with $\mathrm{Na}_{2} \mathrm{O}_{2}$ and subsequent dissolution was performed to demonstrate the feasibility of a pretreatment process on a larger scale. Sodium peroxide was chosen due to the potential of achieving higher actinide recoveries from refractory materials. In this experiment, nominally $10 \mathrm{~g}$ of a graphite-containing residue generated during plutonium casting operations was initially calcined to remove the graphite. Removal of combustible material prior to a large-scale fusion with $\mathrm{Na}_{2} \mathrm{O}_{2}$ is needed due to the large amount of heat liberated during oxidation. Two successive fusions using the residue from the calcination and the residue generated from the initial dissolution allowed recovery of $98 \%$ of the plutonium. The fusion of the residue following the first dissolution was performed at a higher temperature $\left(600^{\circ} \mathrm{C}\right.$ versus $450^{\circ} \mathrm{C}$ during the first fusion). The ability to recover most of the remaining plutonium from the residue suggest the oxidation efficiency of the $\mathrm{Na}_{2} \mathrm{O}_{2}$ fusion improves with higher temperatures similar to results observed with $\mathrm{NpO}_{2}$ fusion. 


\section{Introduction}

The generation of refractory materials containing residual amounts of plutonium and other actinides was frequently a byproduct of past nuclear weapons production activities. The continued storage of approximately $20,000 \mathrm{~kg}$ of incinerator ash at the Rocky Flats Environmental Technology Site is a good example of this practice. The ash, generated by the combustion of job control waste from plutonium-containing gloveboxes, was originally stored for subsequent recovery of plutonium. Traditionally, a nitric acid/fluoride dissolution flowsheet was used to leach plutonium from the ash. Multiple contact times with fresh dissolver solution were generally required to dissolve a majority of the plutonium. Rather than use the traditional, but inefficient, nitric acid/fluoride dissolution flowsheet, the development of a simple solid state fusion for oxidation of plutonium from the $4+$ to the more soluble $6+$ valence state would be more effective and economical. Dissolution of the pretreated residue in dilute nitric acid and subsequent plutonium recovery could then be accomplished using existing F-Canyon facilities at the Savannah River Site.

Fusion reactions are routinely used to solubilize minerals prior to dissolution and elemental analysis. The feasibility of this approach was demonstrated for pretreatment of small samples of refractory $\mathrm{PuO}_{2}$ by fusing with $\mathrm{Na}_{2} \mathrm{O}_{2}$ and potassium superoxide $\left(\mathrm{KO}_{2}\right)$ before subsequent dissolution in $1 \mathrm{M}$ nitric acid. Plutonium recoveries approaching $90 \%$ were obtained.[1] The prospect of using other reagents commonly used for the decomposition of inorganic materials[2] was investigated using a series of small-scale $\left(1 \mathrm{~g}\right.$ of $\left.\mathrm{PuO}_{2}\right)$ experiments. Additional experiments were conducted to determine the feasibility of fusing refractory $\mathrm{NpO}_{2}$ as a pretreatment to dissolution with the most promising materials. Based on the potential of achieving higher actinide recoveries from refractory materials, fusion with $\mathrm{Na}_{2} \mathrm{O}_{2}$ was chosen to demonstrate the feasibility of pretreating and recovering plutonium from a graphite-containing residue.

\section{Small-scale Experiments}

A series of small-scale fusion experiments was performed to determine the feasibility of using analytical reagents commonly used for decomposition of inorganic materials as a pretreatment prior to dissolution of refractory $\mathrm{PuO}_{2}$. The experiments were performed by mixing nominally $1 \mathrm{~g}$ of $\mathrm{PuO}_{2}$ with materials normally used as solubilizing agents for the dissolution of minerals, glasses, and other refractory materials. The $\mathrm{PuO}_{2}$ used in these experiments was calcined at $900^{\circ} \mathrm{C}$ for $2 \mathrm{hr}$ to produce a difficult to dissolve material which could consistently be used to evaluate the efficiency of a variety of reagents in aiding the dissolution process. A summary of the materials and material amounts used in each experiment is provided in Table 1.

The fusion experiments were performed by mixing the $\mathrm{PuO}_{2}$ and fusion materials in a small (30 to $100 \mathrm{ml}$ ) alumina crucible. The crucibles were placed in a muffle furnace and heated to the desired temperature for 1 to $4 \mathrm{hr}$. The fused products were initially leached with water to remove soluble salts. The remaining solids were leached with $8 \mathrm{M}$ nitric acid for plutonium recovery. 
Table 1 Summary of Small-Scale Fusion Experiments

\begin{tabular}{lccc}
\hline \hline \multicolumn{1}{c}{$\begin{array}{c}\text { Fusion } \\
\text { Reagents }\end{array}$} & $\begin{array}{c}\text { Material } \\
\text { Amounts } \\
\text { (grams) }\end{array}$ & $\begin{array}{c}\text { Fusion } \\
\text { Temperature } \\
\text { ('C) }\end{array}$ & $\begin{array}{c}\text { Heating } \\
\text { Time } \\
\text { (hr) }\end{array}$ \\
\hline \hline $\mathrm{Li}_{2} \mathrm{CO}_{3} / \mathrm{Na}_{2} \mathrm{~B}_{4} \mathrm{O}_{7}$ & $2 / 1$ & 1000 & 2 \\
$\mathrm{Na}_{2} \mathrm{~S}_{2} \mathrm{O}_{7} / \mathrm{K}_{2} \mathrm{~S}_{2} \mathrm{O}_{7}$ & $8 / 2$ & 325 & 0.75 \\
$\mathrm{Li}_{2} \mathrm{CO}_{3} / \mathrm{LiBO}_{2}$ & $1 / 1$ & 1000 & 2 \\
$\mathrm{LiOH} / \mathrm{NaNO}_{3} / \mathrm{Na}_{2} \mathrm{~B}_{4} \mathrm{O}_{7}$ & $0.68 / 1 / 0.28$ & 1000 & 2 \\
$\mathrm{KHF}_{2}$ & 1 & 200 & 4 \\
$\mathrm{LiOH} / \mathrm{Na}_{2} \mathrm{~B}_{4} \mathrm{O}_{7}$ & $0.6 / 1$ & 1000 & 2 \\
$\mathrm{Na}_{2} \mathrm{CO}_{3} / \mathrm{Na}_{2} \mathrm{~B}_{4} \mathrm{O}_{7}$ & $2 / 1$ & 1000 & 2 \\
$\mathrm{Na}_{2} \mathrm{CO}_{3} / \mathrm{Na}_{2} \mathrm{~B}_{4} \mathrm{O}_{7}$ & $2 / 1$ & 1000 & 2 \\
$\mathrm{LiBO} \mathrm{O}_{2}$ & 2 & 1000 & 2 \\
$\mathrm{LiF} / \mathrm{LiBO}_{2}(\mathrm{eutectic}$ & $1.9 / 6.2$ & 1000 & 2 \\
$\mathrm{Li} \mathrm{B}_{4} \mathrm{O}_{7} / \mathrm{NaNO}_{3}$ & $2 / 0.5$ & 1000 & 1 \\
$\mathrm{LiBF}$ & 1 & 1000 & 2 \\
\hline
\end{tabular}

The dissolutions were performed by placing the crucible on a hot plate/stirrer to provide agitation and heating. Following a 30 to 60 min dissolution period, the crucible contents were filtered and a sample of the filtrate analyzed for piutonium. The piutonium recovery was then determined based on the solution analysis and the amount of $\mathrm{PuO}_{2}$ used in the experiment. Where appropriate, solid residues were analyzed by $\mathrm{x}$-ray diffraction to identify the fused plutonium species and the spectra of plutonium in nitric acid solution used to identify the plutonium valence.

The most effective material tested for solubilizing the high-fired $\mathrm{PuO}_{2}$ was the $\mathrm{LiCO}_{3} / \mathrm{Na}_{2} \mathrm{~B}_{4} \mathrm{O}_{7}$ mixture which allowed recovery of $90 \%$ of the plutonium. The fused plutonium product was identified as a lithium plutonate $\left(\mathrm{Li}_{3} \mathrm{PuO}_{4}\right)$ by $\mathrm{x}$-ray diffraction. When the $\mathrm{Li}_{3} \mathrm{PuO}_{4}$ was dissolved, the plutonium was further oxidized by nitric acid from the $5+$ to the $6+$ valence state (based on the solution spectra). The use of a 4:1 sodium persulfate $\left(\mathrm{Na}_{2} \mathrm{~S}_{2} \mathrm{O}_{7}\right) /$ potassium persulfate $\left(\mathrm{K}_{2} \mathrm{~S}_{2} \mathrm{O}_{7}\right)$ mixture was somewhat effective in solubilizing the high-fired $\mathrm{PuO}_{2}$. The experiment was performed by adapting an analytical procedure for high-fired actinide oxides reported by Angeletti and Bartscher.[3] Interestingly, the dissolution of the fused plutonium product was in the 4+ oxidation state. A small sample of the fused product was examined by $\mathrm{x}$-ray diffraction, but no plutonium compounds could be identified. The drawbacks to this procedure include the large 10:1 excess of the persulfate mixture required for the fusion and the concern of introducing large amounts of sulfate into a nitric acid-based plutonium recovery operation which would cause a corrosion problem with the $304 \mathrm{~L}$ stainless steel equipment.

Surprisingly, the use of other fusion reagents containing both oxidizers and fluxing agents similar to the $\mathrm{Li}_{2} \mathrm{CO}_{3} / \mathrm{Na}_{2} \mathrm{~B}_{4} \mathrm{O}_{7}$ mixture were not as effective in solubilizing high-fired $\mathrm{PuO}_{2}$. In several cases lithium ion was also present in the mixture. Its presence, although the mechanism is not understood, may play a role in successful oxidative fusion. Material combinations similar to the 
$\mathrm{Li}_{2} \mathrm{CO}_{3} / \mathrm{Na}_{2} \mathrm{~B}_{4} \mathrm{O}_{7}$ mixture which were investigated included: $\mathrm{Li}_{2} \mathrm{CO}_{3} /$ lithium metaborate $\left(\mathrm{LiBO}_{2}\right)$, lithium hydroxide $(\mathrm{LiOH}) /$ sodium nitrate $\left(\mathrm{NaNO}_{3}\right) / \mathrm{Na}_{2} \mathrm{~B}_{4} \mathrm{O}_{7}$, sodium carbonate $\left(\mathrm{Na}_{2} \mathrm{CO}_{3}\right) / \mathrm{Na}_{2} \mathrm{~B}_{4} \mathrm{O}_{7}$, lithium fluoride $(\mathrm{LiF}) / \mathrm{LiBO}$ (eutectic mixture), and lithium tetraborate $\left(\mathrm{Li}_{2} \mathrm{~B}_{4} \mathrm{O}_{7}\right) / \mathrm{NaNO}_{3}$. The ability of several other material combinations to oxidize refractory $\mathrm{PuO}_{2}$ were also investigated. The use of a $\mathrm{LiOH} / \mathrm{Na}_{2} \mathrm{~B}_{4} \mathrm{O}_{7}$ mixture was unsuccessful, presumably due to the lack of an oxidizer. The use of $\mathrm{LiBO}_{2}$ and the $\mathrm{Li}_{2} \mathrm{~B}_{4} \mathrm{O}_{7} / \mathrm{NaNO}_{3}$ mixture may have been limited by the relatively high melting point of the starting material(s) which hindered the ability of the reagent(s) from contacting the $\mathrm{PuO}_{2}$. The $\mathrm{LiBO}_{2}$ fusion also lacked the presence of an oxidizing carbonate or nitrate in the fusion mixture.

Two experiments were performed using potassium hydrogen fluoride $\left(\mathrm{KHF}_{2}\right)$ and lithium tetrafluoroborate $\left(\mathrm{LiBF}_{4}\right)$ as fusion reagents. These materials should produce a more soluble plutonium compound by fluorination with the expected product being plutonium tetrafluoride $\left(\mathrm{PuF}_{4}\right)$. In anticipation of producing $\mathrm{PuF}_{4}$, the fused product was leached with a $2 \mathrm{M}$ nitric acid/0.5M aluminum nitrate $\left(\mathrm{Al}\left(\mathrm{NO}_{3}\right)_{3}\right)$ solution. Dissolution of the fused $\mathrm{KHF}_{2} / \mathrm{PuO}_{2}$ mixture resulted in the recovery of $16 \%$ of the plutonium. An optimization of the processing conditions would likely resuit in an increased recovery. Only a trace of plutonium was detected in the filtrate following dissolution of the product from the $\mathrm{LiBF}_{4}$ fusion.' The failure of this fusion was attributed to the high furnace temperature $\left(1000^{\circ} \mathrm{C}\right)$ which likely decomposed the $\mathrm{LiBF}_{4}$ before it had a chance to react with the $\mathrm{PuO}_{2}$. The plutonium recoveries from each of the smallscale experiment are summarized in Table 2.

Table 2 Plutonium Recovery Following Small-Scale Fusions

\begin{tabular}{lc}
\hline \hline \multicolumn{1}{c}{$\begin{array}{c}\text { Fusion } \\
\text { Reagents }\end{array}$} & $\begin{array}{c}\text { Plutonium } \\
\text { Recovery } \\
(\%)\end{array}$ \\
\hline $\mathrm{Li}_{2} \mathrm{CO}_{3} / \mathrm{Na}_{2} \mathrm{~B}_{4} \mathrm{O}_{7}$ & 90 \\
$\mathrm{Na}_{2} \mathrm{~S}_{2} \mathrm{O}_{7} / \mathrm{K}_{2} \mathrm{~S}_{2} \mathrm{O}_{7}$ & 56 \\
$\mathrm{Li}_{2} \mathrm{CO}_{3} / \mathrm{LiBO}_{2}$ & 34 \\
$\mathrm{LiOH} / \mathrm{Na}_{2} \mathrm{~B}_{4} \mathrm{O}_{7} / \mathrm{NaNO}_{3}$ & 25 \\
$\mathrm{KHF}{ }_{2}$ & 16 \\
$\mathrm{LiOH} / \mathrm{Na}_{2} \mathrm{~B}_{4} \mathrm{O}_{7}$ & 12 \\
$\mathrm{Na}_{2} \mathrm{CO}_{3} / \mathrm{Na}_{2} \mathrm{~B}_{4} \mathrm{O}_{7}$ & 10 \\
$\mathrm{Na}_{2} \mathrm{CO}_{3} / \mathrm{Na}_{2} \mathrm{~B}_{4} \mathrm{O}_{7}$ & 10 \\
$\mathrm{LiBO}$ & 3 \\
$\mathrm{LiF}_{2} / \mathrm{LiBO}_{2}($ eutectic mixture $)$ & 2 \\
$\mathrm{Li}_{2} \mathrm{~B}_{4} \mathrm{O}_{7} / \mathrm{NaNO}_{3}$ & $<1$ \\
$\mathrm{LiBF}_{4}$ & $<1$ \\
\hline
\end{tabular}




\section{Neptunium Oxide Fusion}

A small-scale experiment was performed with high-fired neptunium oxide $\left(\mathrm{NpO}_{2}\right)$ to measure the effectiveness of fusion with a $\mathrm{Li}_{2} \mathrm{CO}_{3} / \mathrm{Na}_{2} \mathrm{~B}_{4} \mathrm{O}_{7}$ mixture as a pretreatment prior to dissolution. High-fired $\mathrm{NpO}_{2}$ is quite refractory and can be as difficult to dissolve as high-fired $\mathrm{PuO}_{2}$. The $\mathrm{NpO}_{2}$ used in this experiment was heated to $900^{\circ} \mathrm{C}$ prior to fusion. Nominally $2 \mathrm{~g}$ of $\mathrm{NpO}_{2}$ were mixed with $4 \mathrm{~g} \mathrm{Li}_{2} \mathrm{CO}_{3}$ and $2 \mathrm{~g} \mathrm{Na}_{2} \mathrm{~B}_{4} \mathrm{O}_{7}$ and fused at $1000^{\circ} \mathrm{C}$ for $1 \mathrm{hr}$. The $\mathrm{Li}_{2} \mathrm{CO}_{3} / \mathrm{Na}_{2} \mathrm{~B}_{4} \mathrm{O}_{7}$ fusion oxidized $25 \%$ of the $\mathrm{NpO}_{2}$ to a neptunium (VI) species that was easily dissolved in nitric acid. The valence of the neptunium was determined by the solution spectrum. The insoluble residue from this experiment was dried and fused with $\mathrm{Na}_{2} \mathrm{O}_{2}\left(2 \mathrm{~g} \mathrm{Na}_{2} \mathrm{O}_{2} / \mathrm{g} \mathrm{NpO}_{2}\right)$ at $380^{\circ} \mathrm{C}$ for $4 \mathrm{hr}$. Following the fusion, approximately $70 \%$ of the $\mathrm{NpO}_{2}$ residue dissolved in water to yield a basic solution of neptunium (VII), identified by the neptunium (VII) adsorption spectrum. The remainder of the neptunium was recovered as a neptunium (VI) solution by dissolving in $8 \mathrm{M}$ nitric acid.

To understand the role of temperature in the oxidation of $\mathrm{NpO}_{2}$ to higher valence states, a series of $\mathrm{Na}_{2} \mathrm{O}_{2}$ fusions was performed with step-wise increases in temperature. High-fired $\left(900^{\circ} \mathrm{C}\right)$ $\mathrm{NpO}_{2}$ was combined with $\mathrm{Na}_{2} \mathrm{O}_{2}$ equal to 2.8 times its mass. The fusion mixture was heated for $2-3 \mathrm{hr}$ at $300-500^{\circ} \mathrm{C}$ in $50^{\circ} \mathrm{C}$ steps, and sampled after heating at each temperatue. The samples were washed with $2 \mathrm{M} \mathrm{NaOH}$ to dissolve neptunium (VII); the base-insoluble fraction was then dissolved in $8 \mathrm{M}$ nitric acid. The ratio of neptunium (VII) to neptunium (VI) was determined by assay of the solutions. Essentially all of the $\mathrm{NpO}_{2}$ was converted to soluble higher valences. The results from each fusion are shown in Table 3.

Table 3 Fusion of $\mathrm{NpO}_{2}$ with Increasing Temperature

\begin{tabular}{cccc}
\hline \hline Temperature & Np (VI) & Np (VI) & $\frac{\text { Np (VII) }}{\frac{\text { Total Np }}{(\%)}}$ \\
\hline 300 & $(\mathrm{mg})$ & $(\mathrm{mg})$ & - \\
350 & $\mathrm{NR}$ & $\mathrm{NR}$ & 28 \\
400 & 29.6 & 76.7 & 68 \\
450 & 50.9 & 24 & 66 \\
500 & 13.6 & 7 & 95 \\
\hline NR - No Reaction & 417 & 24 &
\end{tabular}

From data in Table 3, one can see that the ratio of neptunium (VII) to neptunium (VI) increased with temperature up to $500^{\circ} \mathrm{C}$. To extend the data to higher temperatures, additional experiments were performed from 550 to $650^{\circ} \mathrm{C}$. In these experiments, the neptunium oxidations were performed by mixing 6.5 mole $\mathrm{Na}_{2} \mathrm{O}_{2} /$ mole $\mathrm{NpO}_{2}$ and fusing for $2-3 \mathrm{hr}$. Dissolution of the fused products in $2 \mathrm{M} \mathrm{NaOH}$ demonstrated that $99 \%$ of the $\mathrm{NpO}_{2}$ was converted to a green ternary neptunium (VII) oxide powder, presumably by equation (1). 


$$
\mathrm{NpO}_{2}+3 / 2 \mathrm{Na}_{2} \mathrm{O}_{2} \rightarrow \mathrm{Na}_{3} \mathrm{NpO}_{5}
$$

Oxidation at $620^{\circ} \mathrm{C}$ with a 1.4 mole $\mathrm{Na}_{2} \mathrm{O}_{2}$ to 1 mole $\mathrm{NpO}_{2}$ ratio yielded a brown powder, which was probably the ternary neptunium (VI) oxide formed by equation (2).

$$
\mathrm{NpO}_{2}+\mathrm{Na}_{2} \mathrm{O}_{2} \rightarrow \mathrm{Na}_{2} \mathrm{NpO}_{4}
$$

Another 1.4 mole of $\mathrm{Na}_{2} \mathrm{O}_{2}$ was added, and the mixture heated another $2 \mathrm{hr}$. The product was a green solid that analyzed $95 \%$ neptunium (VII). The minimum amount of $\mathrm{Na}_{2} \mathrm{O}_{2}$ to achieve complete conversion of $\mathrm{NpO}_{2}$ to neptunium (VI) was judged to be approximately $300 \%$ of the stoichiometric requirement. The temperature limit of the fusion is probably the melting point of $\mathrm{Na}_{2} \mathrm{O}_{2}, 675^{\circ} \mathrm{C}$,[4] where molten $\mathrm{Na}_{2} \mathrm{O}_{2}$ could attack the fusion vessel.

An interesting sidelight of the fusion of $\mathrm{NpO}_{2}$ with $\mathrm{Na}_{2} \mathrm{O}_{2}$ is the separation of plutonium-238 from neptunium-237 during neptunium oxidation to neptunium (VII). Neptunium that has been used to produce plutonium-238 retains enough of the plutonium-238 that alpha-pulse height analysis shows only $10-20 \%$ neptunium in the alpha spectrum. After oxidation to neptunium (VII), the spectrum of the recovered neptunium in the base-soluble fraction averaged $91 \%$ neptunium-237 alpha.

\section{Fusion of Graphite Fines Residue}

Fusion of refractory $\mathrm{PuO}_{2}$ with $\mathrm{Na}_{2} \mathrm{O}_{2}$ and $\mathrm{Li}_{2} \mathrm{CO}_{3} / \mathrm{Na}_{2} \mathrm{~B}_{4} \mathrm{O}_{7}$ mixture prior to dissolution clearly achieved the highest recoveries during recent and past[1] small-scale experiments. Based on this work and the fusion experiments performed with high-fired $\mathrm{NpO}_{2}$, it appears the use of $\mathrm{Na}_{2} \mathrm{O}_{2}$ has the higher potential for the development of a plutonium recovery process. To test the ability of $\mathrm{Na}_{2} \mathrm{O}_{2}$ to solubilize $\mathrm{PuO}_{2}$ on a multi-gram scale, an experiment was designed to recover plutonium from a graphite-containing residue generated during the cleaning of casting molds at the Los Alamos National Laboratory (LANL). The nominal composition of the "graphite fines" residue is given in Table 4.

Table 4 Composition of Graphite Fines Residue

\begin{tabular}{lc}
\hline \hline \multicolumn{1}{c}{ Component } & $\begin{array}{c}\text { Composition } \\
\text { (wt\%) }\end{array}$ \\
\hline Graphite (Carbon) & 75 \\
Calcium Fluoride & 9 \\
Magnesium Oxide & 7 \\
Plutonium Oxide & 7 \\
Minor Oxides & 2 \\
\hline
\end{tabular}


Before attempting the fusion with the actual graphite fines residue, a surrogate material was prepared to demonstrate the pretreatment process. A $4 \mathrm{~g}$ mixture containing 73 wt\% graphite, 15 wt\% calcium fluoride $\left(\mathrm{CaF}_{2}\right)$, and $12 \mathrm{wt} \%$ cerium oxide $\left(\mathrm{CeO}_{2}\right)$, the surrogate for $\mathrm{PuO}_{2}$, was prepared. The surrogate was mixed with a $30 \%$ excess in the amount of $\mathrm{Na}_{2} \mathrm{O}_{2}(44.3 \mathrm{~g})$ required to fully oxidize the graphite (see equation 3 ).

$$
\mathrm{C}+2 \mathrm{Na}_{2} \mathrm{O}_{2} \rightarrow \mathrm{CO}_{2}+2 \mathrm{Na}_{2} \mathrm{O}
$$

The mixture was placed in a $250 \mathrm{ml}$ alumina crucible and fused at $450^{\circ} \mathrm{C}$ for $2 \mathrm{hr}$. During the heating period, the crucible shattered due to thermal shock from the heat liberated during the reaction of the graphite with $\mathrm{Na}_{2} \mathrm{O}_{2}$. The estimated heat of reaction (for equation 3) at $450^{\circ} \mathrm{C}$ is $48 \mathrm{kcal} / \mathrm{mole}$.[4] Due to the large amount of heat liberated from the oxidation of the graphite by the $\mathrm{Na}_{2} \mathrm{O}_{2}$ and the large amount of reagent required to perform the fusion, calcination of the graphite fines (and any other residue containing combustible materials) prior to fusion should be performed. A subsequent fusion of the simulated graphite fines following calcination at $1000^{\circ} \mathrm{C}$ was performed without difficulty.

To demonstrate the pretreatment of actual graphite fines residue with $\mathrm{Na}_{2} \mathrm{O}_{2}$ prior to dissolution and recovery of plutonium, nominally $10 \mathrm{~g}$ of material were placed in a $100 \mathrm{ml}$ alumina crucible and calcined at $900^{\circ} \mathrm{C}$ until a constant mass was achieved. Nine hours at temperature were required and approximately $75 \%$ of the residue mass was lost during the calcination. The calcined residue was then mixed with $0.924 \mathrm{~g}$ of $\mathrm{Na}_{2} \mathrm{O}_{2}$. The mass of $\mathrm{Na}_{2} \mathrm{O}_{2}$ was based on the uncalcined residue containing nominally $7 \mathrm{wt} \%$ plutonium, the stoichiometry of equation (4), and $100 \%$ excess reagent.

$$
\mathrm{PuO}_{2}+2 \mathrm{Na}_{2} \mathrm{O}_{2} \rightarrow \mathrm{Na}_{4} \mathrm{PuO}_{5}+1 / 2 \mathrm{O}_{2}
$$

The calcined residue and $\mathrm{Na}_{2} \mathrm{O}_{2}$ were heated at $450^{\circ} \mathrm{C}$ for $2 \mathrm{hr}$. The fused product was transferred to a $250 \mathrm{ml}$ beaker and dissolved with $8 \mathrm{M}$ nitric acid. The beaker contents were stirred and heated at $80-90^{\circ} \mathrm{C}$ for $1 \mathrm{hr}$. A watch glass containing water was placed on the beaker to minimize evaporation during the heating period. After cooling, residual solids were filtered using $0.45 \mu \mathrm{m}$ paper. The filtrate volume was measured and the solution analyzed for plutonium and americium by liquid scintillation counting and a gamma scan.

The filter paper and solids were transferred into a $100 \mathrm{ml}$ alumina crucible and heated at $800^{\circ} \mathrm{C}$ for 2 hours to destroy the filter paper. A second fusion was then performed using the residue by adding $0.524 \mathrm{~g}$ of $\mathrm{Na}_{2} \mathrm{O}_{2}$, mixing, and heating at $600^{\circ} \mathrm{C}$ for $2 \mathrm{hr}$. The fused product was dissolved in nominally $60 \mathrm{ml}$ of $8 \mathrm{M}$ nitric acid. The acid was added directly to the crucible since the material was sticky and could not be removed. The sticky consistency of the fused product was attributed to the absorption of moisture while the crucible was stored in the glovebox for approximately 8 days. A stirring bar was added to stir the crucible contents while heating at $80-90^{\circ} \mathrm{C}$ for approximately $1 \mathrm{hr}$. A watch glass containing water was placed on the crucible to minimize evaporation during the heating period. Once cool, the crucible contents were filtered 
through a piece of $0.45 \mu \mathrm{m}$ filter paper. The filtrate volume was measured and the solution analyzed for plutonium and americium by liquid scintillation counting and a gamma scan.

The small amount of remaining solids and filter paper were placed into a $100 \mathrm{ml}$ alumina crucible and heated at $600^{\circ} \mathrm{C}$ for $2 \mathrm{hr}$. The residue and approximately $75 \mathrm{ml}$ of a $15.7 \mathrm{M}$ nitric acid/0.1M potassium fluoride (KF) solution were transferred to a $250 \mathrm{ml}$ beaker which was covered with a watch glass containing water, stirred, and heated under reflux conditions for $2 \mathrm{hr}$. The solution was cooled and filtered through $0.45 \mu \mathrm{m}$ filter paper demonstrating that all of the remaining solids dissolved. The filtrate volume was measured and the solution analyzed for plutonium and americium by liquid scintillation counting and gamma scan.

The amounts of plutonium recovered from the graphite fines residue following each of the dissolutions are given in Table 5.

Table 5 Plutonium Recovery from Graphite Fines Residue

\begin{tabular}{|c|c|c|}
\hline Dissolution & $\begin{array}{l}\text { Recovered Plutonium } \\
\text { (g) }\end{array}$ & $\begin{array}{c}\text { Fraction Recovered } \\
(\%)\end{array}$ \\
\hline Following $1^{\text {st }}$ Fusion & 0.25 & 54 \\
\hline Following $2^{\text {nd }}$ Fusion & 0.20 & 44 \\
\hline Nitric Acid/KF & 0.01 & 2 \\
\hline Total & 0.46 & 100 \\
\hline
\end{tabular}

The recovery of essentially all the remaining plutonium following the second fusion at $600^{\circ} \mathrm{C}$ suggest the oxidation 'efficiency of the $\mathrm{Na}_{2} \mathrm{O}_{2}$ fusion improves with higher temperatures, similar to the fusion of $\mathrm{NpO}_{2}$, at least up to the melting point at $675^{\circ} \mathrm{C}$.

\section{Conclusions}

Small-scale experiments have demonstrated the feasibility of fusing refractory $\mathrm{PuO}_{2}$ with a series of materials commonly used to decompose minerals as a pretreatment to dissolution and subsequent recovery operations. The most effective material tested for solubilizing high-fired $\mathrm{PuO}_{2}$ was a $\mathrm{LiCO}_{3} / \mathrm{Na}_{2} \mathrm{~B}_{4} \mathrm{O}_{7}$ mixture which facilitated recovery of $90 \%$ of the plutonium. The fused product was identified as a lithium plutonate $\left(\mathrm{Li}_{3} \mathrm{PuO}_{4}\right)$ by $\mathrm{x}$-ray diffraction. Several other materials were somewhat effective in solubilizing the refractory $\mathrm{PuO}_{2}$. Fusion with a $\mathrm{Na}_{2} \mathrm{~S}_{2} \mathrm{O}_{7} / \mathrm{K}_{2} \mathrm{~S}_{2} \mathrm{O}_{7}$ mixture resulted in a $56 \%$ plutonium recovery following dissolution in $8 \mathrm{M}$ nitric acid; however, a large excess of the persulfate mixture is required and the introduction of large amounts of sulfate into nitric acid-based recovery operations would cause corrosion problems with $304 \mathrm{~L}$ stainless steel equipment. Other materials showing some promise included $\mathrm{Li}_{2} \mathrm{CO}_{3} / \mathrm{LiBO} 2$ and $\mathrm{LiOH} / \mathrm{Na}_{2} \mathrm{~B}_{4} \mathrm{O}_{7} / \mathrm{NaNO}_{3}$ mixtures which resulted in the recovery of 34 and $25 \%$ of the plutonium following dissolution of the fused product in $8 \mathrm{M}$ nitric acid. 
The use of a $\mathrm{Li}_{2} \mathrm{CO}_{3} / \mathrm{Na}_{2} \mathrm{~B}_{4} \mathrm{O}_{7}$ mixture in solubilizing high-fired $\mathrm{NpO}_{2}$ was not as effective as demonstrated for refractory $\mathrm{PuO}_{2}$. In a small-scale experiment, $25 \%$ of the $\mathrm{NpO}_{2}$ was oxidized to a neptunium (VI) species that dissolved in nitric acid. The remaining neptunium was then easily recovered from the residue by fusing with $\mathrm{Na}_{2} \mathrm{O}_{2}$; approximately $70 \%$ of the neptunium dissolved in water to yield a basic solution of neptunium (VII) (identified by the adsorption spectrum). The remainder of the neptunium was recovered as a neptunium (VI) solution by dissolving in $8 \mathrm{M}$ nitric acid.

A series of experiments with progressively higher reaction temperatures demonstrated that $\mathrm{Na}_{2} \mathrm{O}_{2}$ fusion of high-fired $\mathrm{NpO}_{2}$ favored the formation of neptunium (VII) compounds as the fusion temperature increased. At $550^{\circ} \mathrm{C}, 99 \%$ of the neptunium was oxidized to a neptunium (VII) ternary oxide. Oxidation of the neptunium to the 7+ valance and dissolution in dilute $\mathrm{NaOH}$ can be used to separate neptunium from the residual plutonium-238 alpha activity, if the neptunium has been used for past plutonium-238 production.

The effectiveness of a $\mathrm{Na}_{2} \mathrm{O}_{2}$ fusion to produce an acid soluble actinide product was judged superior to other materials tested during these studies. This conclusion was based on previous work and the small-scale $\mathrm{PuO}_{2}$ and $\mathrm{NpO}_{2}$ fusions. In a larger scale demonstration of the $\mathrm{Na}_{2} \mathrm{O}_{2}$ fusion using a graphite fines residue from LANL, the necessity of calcining any combustible material prior to the fusion was demonstrated. Excessive heat and gases generated by the oxidation of combustible material by the $\mathrm{Na}_{2} \mathrm{O}_{2}$ would likely present problems. The large-scale experiment also indicated that the plutonium oxidation efficiency of $\mathrm{Na}_{2} \mathrm{O}_{2}$ will likely improve with increasing temperatures, similar to the reaction with refractory $\mathrm{NpO}_{2}$.

\section{Acknowledgements}

Funding for this investigation was made possible through the support provided by the Savannah River Technology Center Strategic Research and Development Program.

\section{References}

1. D. G. Karraker, "Oxidation of Pu-Bearing Solids: A Process for Pu Recovery from Rocky Flats Incinerator Ash," Report WSRC-TR-97-0231, Westinghouse Savannah River Company, Aiken, SC (July 1997).

2. Z. Šulcek and P. Povondra, Methods of Decomposition in Inorganic Analysis, CRC Press, Inc. Boca Raton, FL (1989).

3. L. M. Angeletti and W. J. Bartscher, Anal. Chim. Acta, 60. 238, 1972.

4. J. A. Dean, Editor, Lange's Handbook of Chemistry, $13^{\text {th }}$ Edition, McGraw-Hill Book Company, New York, NY (1985). 